\title{
PROFIT DISTRIBUTION MANAGEMENT PADA BANK SYARIAH
}

\author{
Fitriyana ${ }^{1}$, Komala Ardiyani ${ }^{2}$, Catur Ragil Sutrisno ${ }^{3}$ \\ 1,2,3Universitas Pekalongan \\ $\triangle$ caturunikal@gmail.com
}

\begin{abstract}
This study aims to analyze the influence of the proportion of third party funds (DPK), operational cost to operating income (BOPO), financing to deposit ratio (FDR), bank size and capital adequacy ratio (CAR) to profit distribution management at Sharia Bank. The population is all Sharia Commercial Banks in Indonesia, the period of 2012-2015. Samples were taken using purposive sampling technique. The results show that third party funds (DPK), finance to deposit ratio (FDR) and bank size have no significant effect on profit distribution management (PDM). While BOPO and capital adequacy ratio (CAR) have a significant effect on profit distribution management (PDM).
\end{abstract}

Keywords : Profit Distribution Management, DPK, BOPO, FDR, bank size and CAR.

\section{LATAR BELAKANG}

Bank syariah mendasarkan pada prinsip syariah yang mengedepankan prinsip muamalah, keadilan dan kebersamaan dalam berusaha, baik dalam memperoleh keuntungan maupun dalam menghadapi risiko. Dalam proses penghimpunan dana maupun penyaluran dana, bank syariah menerapkan sistem bagi hasil dengan cara perhitungan bagi pendapatan (revenue sharing) maupun bagi laba (profit sharing) dan bagi risiko (risk sharing) (Yaya dkk., 2009).

Menurut Bank Indonesia, profit distribution (PD) adalah suatu pendistribusi atas keuntungan yang diperoleh oleh bank syariah kepada para nasabah berdasarkan proporsi atau rasio yang disepakati setiap periodenya, baik oleh pihak bank syariah ataupun oleh para nasabahnya. profit distribution diatur berdasarkan produk yang menjadi pilihan nasabah terhadap bank syariah, serta persetujuan nisbahnya.

Fenomena yang terjadi menunjukkan bahwa bank syari'ah tidak melakukan profit distribution secara sebenarnya, melainkan melakukan Profit Distribution Management (PDM) yang mengacu pada suku bunga bank konvensional. Hal ini terkait erat dengan tipe nasabah di Indonesia. Penelitian yang dilakukan oleh Khairunnisa (2002) menemukan bahwa nasabah mengincar profit maximization". Survei dari Karim (2005), juga menyebutkan bahwa 70\% nasabah perbankan syari'ah adalah nasabah yang berada pada floating segment, yang sensitif pada tingkat keuntungan. Sedangkan menurut Muhlis (2011), dalam disertasinya memiliki kesimpulan utama bahwa perilaku menabung di bank syari'ah paling dipengaruhi oleh tingkat bagi hasil (profit distribution). Hasil penelitian tersebut memberi implikasi bahwa sangatlah penting bagi bank syari'ah untuk menjaga kualitas tingkat bagi hasil. Nasabah akan selalu memperhatikan dan memperhitungkan tingkat bagi hasil yang diperoleh dalam investasi pada bank syari'ah. Logikanya jika tingkat bagi hasil terlalu rendah dari pada 
bank lain terutama dibanding dengan suku bunga bank konvensional, maka tingkat kepuasan deposan akan menurun dan kemungkinan besar nasabah akan memindahkan dananya pada bank lain (displacement fund). Secara tidak langsung bank syari'ah dituntut untuk melakukan PDM yang mengacu pada suku bunga.

Sistem syari'ah ini menawarkan keadilan, transparansi, akuntabilitas dan saling percaya diantara para pelaku ekonomi. Sistem ekonomi dunia saat ini didominasi oleh segelintir pemilik modal dan para kapitalis yang memiliki pengaruh yang luar biasa dalam pergerakan roda ekonomi, yang pada akhirnya banyak menimbulkan korban sehingga keberadaan bank syari'ah ini diharapkan mampu memberikan solusi atas keadaan tersebut. Permasalahan terkait distribusi bagi hasil (PDM) pada bank syari'ah adalah kurangnya pemahaman oleh nasabah sebagai investor terkait laporan keuangan sebagai indikator baik buruknya profitabilitas bank syari'ah yang selanjutnya akan mempengaruhi besar kecilnya imbalan bagi hasil kepada nasabahnya. Tidak semua nasabah (investor yang menghimpun dananya ke bank) memahami bagaimana sebenarnya bank syari'ah yang baik atau bagaimana mengetahui bahwa bank syari'ah memiliki profitabilitas yang baik sehingga imbal bagi hasil yang diterima nasabah akan tinggi.

Penelitian terdahulu yang telah dilakukan oleh Rizaludin dan Siswantoro (2013) menggunakan variabel proporsi dana pihak ketiga (DPK), biaya operasional terhadap pendapatan operasional (BOPO), efektivitas financing to deposit ratio (FDR) dan ukuran bank syariah sebagai variabel independent untuk mengetahui pengaruhnya terhadap Profit Distribution Management.

Proporsi dana pihak ketiga adalah proporsi atas dana yang diperoleh oleh bank syariah dalam yang dihimpun oleh bank syariah tersebut, dimana dana tersebut merupakan dana uang masuk ke bank syariah, yang berasal dari nasabah selain pemodal maupun peminjam. Menurut Farook (dalam Rizaludin dan Siswantoro, 2013) bahwa bank syariah dengan proporsi dana pihak ketiga yang lebih kecil daripada dana pemegang saham cenderung tidak mengelola PDM dengan baik yang mengacu pada suku bunga. Ukuran bank syariah sebagai salah satu kekuatan dalam menjalankan kegiatan operasionalnya, dimana salah satu indikatornya adalah dengan total aset yang dimiliki oleh bank syariah itu sendiri. Menurut Boyd dan Runkle (dalam Rizaludin dan Siswantoro, 2013), ukuran bank sering dikaitkan dengan konsep economic of scale. Teori ekonomi menjelaskan bahwa jika industri mengalami economic of scale, institusi bisa lebih efisien untuk menghasilkan biaya yang lebih rendah. Diharapkan ekonomi skala atau ukuran bank berpengaruh positif terhadap profitabilitas bank. Financing to Deposit Ratio (FDR) menurut Bank Indonesia adalah rasio pembiayaan terhadap dana pihak ketiga yang diterima oleh bank. FDR digunakan untuk bank syariah, sedangkan LDR untuk bank umum. Menurut Suryani (dalam Rizaludin dan Siswantoro, 2013) bahwa "Financing to Deposit Ratio (FDR) merupakan rasio yang digunakan untuk mengukur likuiditas suatu bank dalam membayar kembali penarikan dana yang dilakukan deposan dengan mengandalkan pembiayaan yang diberikan sebagai sumber likuiditasnya, yaitu dengan cara membagi jumlah pembiayaan yang diberikan oleh bank terhadap Dana Pihak Ketiga (DPK)". Kemudian likuiditas yang rendah 
menggambarkan kurang baiknya posisi likuiditas suatu bank. Sehingga bisa dikatakan financing to deposit ratio bisa berpengaruh negatif atas Profit Distribution Management. Menurut Purwanto (dalam Rizaludin dan Siswantoro, 2013) ini menandakan jika dilihat dari sisi lain FDR yang tinggi dapat juga dikatakan bahwa perbankan syariah mengalami likuiditas yang sangat ketat. Likuiditas yang sangat ketat akan menimbulkan risiko likuiditas yang tinggi.

Biaya operasional pendapatan operasional atau rasio BOPO merupakan rasio yang dapat digunakan untuk melihat tingkat efisiensi dan kemampuan bank dalam menunjang kegiatan operasionalnya. Saat ini terdapat bank syariah yang memiliki rasio melebihi $100 \%$, sedangkan batas maksimum yang diperbolehkan oleh Bank Indonesia yaitu sebesar $90 \%$ hinga 100\%. Bila kita artikan kembali bahwa perbankan yang memiliki rasio BOPO tinggi mengindikasikan bahwa bank tersebut belum mampu dalam menunjang kegiatan operasionalnya. Dari pemaparan tersebut dapat diambil kesimpulan bahwa semakin tinggi BOPO maka Profit Distribution Management akan semakin kecil.

Dalam penelitian ini peneliti menambahkan variabel rasio kecukupan modal (CAR) sebagai variabel independen. Kecukupan Modal (KM) menggambarkan kemampuan bank dalam mempertahankan modal yang mencukupi untuk menutupi risiko kerugian yang mungkin timbul dari penanaman dana dalam aset-aset produktif yang mengandung risiko, serta untuk pembiayaan dalam aset tetap dan investasi. KM diukur dengan rasio CAR (Capital Adequacy Ratio). Penetapan CAR pada tingkat tertentu dimaksudkan agar bank memiliki kemampuan modal yang cukup untuk meredam kemungkinan timbulnya risiko sebagai akibat berkembang atau meningkatnya ekspansi aset terutama aset yang dikategorikan dapat memberikan hasil dan sekaligus mengandung risiko. Tingginya rasio ini dapat melindungi nasabah dan dapat meningkatkan kepercayaan nasabah terhadap bank (Rahman, 2004). CAR yang tinggi membuat bank mampu meredam risiko-risiko yang muncul. Sehingga manajer bank lebih berani melakukan PDM yang mengacu pada suku bunga dikarenakan bank sedang dalam kondisi yang aman. Berdasarkan hal tersebut, penulis merumuskan masalah pada bagaimana pengaruh proporsi DPK, BOPO, FDR, ukuran bank dan CAR terhadap Profit Distribution Management pada Bank Syariah di Indonesia.

Tujuan penelitian ini untuk menganalisis bagaimana pengaruh variabel-variabel tersebut terhadap Profit Distribution Management pada Bank Syariah di Indonesia.

\section{TEORI DAN METODE}

\subsection{Teori Stakeholder}

Stakeholder merupakan individu, sekelompok manusia, komunitas atau masyarakat baik secara keseluruhan maupun secara parsial yang memiliki hubungan serta kepentingan terhadap perusahaan.

Bagi bank, deposan merupakan stakeholder yang keberadaannya vital, karena bank membutuhkan dana dari deposan sebagai salah satu fungsi operasional bank 
untuk going concern dalam bentuk tabungan, deposito dan giro. Hal tersebut mengakibatkan setiap bank (bank syariah ataupun bank konvensional) untuk bersaing memperoleh pangsa pasar deposan, yaitu bank konvensional menggunakan suku bunga dan bank syariah dengan sistem bagi hasilnya untuk menarik deposan. Menurut Karim (2004), Khairunnisa (2002) dan Husnelly (2003) tipe deposan di Indonesia sebagian besar termasuk dalam kelompok floating segment. Floating segment merupakan segmen yang peka terhadap harga dan hukum Islam. Dalam segmen ini sangat tinggi kemungkinan deposan memindahkan dananya pada bank lain (displacement fund) karena perbedaan return antara bank konvensional dan bank syariah. Jika bank konvensional yang mengacu pada BI rate memiliki tingkat return yang lebih tinggi, maka bank syariah terpaksa (forced) melakukan Profit Distribution Management yang mengacu pada suku bunga (BI rate), sehingga tingkat return bagi hasil di bank syariah tidak kalah bersaing. Oleh karena itu, PDM menjadi salah satu langkah yang digunakan manajer bank syariah untuk memanage stakeholder-nya dan bersaing dengan bank yang lain.

\subsection{Bank Syariah}

Pasal 1 Undang-undang No. 21 Tahun 2008 tentang perbankan syariah, menyebutkan bahwa bank adalah badan usaha yang menghimpun dana masyarakat dalam bentuk simpanan dan menyalurkannya kepada masyarakat dalam bentuk kredit dan atau bentuk-bentuk lainnya dalam rangka meningkatkan taraf hidup rakyat banyak. Bank syariah adalah bank yang beroperasi sesuai dengan prinsip-prinsip syariat Islam atau bank yang tata cara beroperasinya mengacu pada ketentuan AlQuran dan Al-Hadits.

\subsection{Mekanisme Penghimpunan Dana Bank Syariah}

Penghimpunan dana bank syariah dari masyarakat dilakukan dengan menggunakan instrument tabungan, deposito dan giro yang secara total biasa disebut dana pihak ketiga. Berdasarkan fatwa Dewan Syariah Nasional (DSN), prinsip penghimpunan dana yang digunakan dalam bank syariah ada dua, yaitu prinsip wadiah dan prinsip mudharabah. Wadiah berati titipan dari satu pihak ke pihak lain, baik individu maupun badan hukum yang harus dijaga dan dikembalikan oleh yang penerima titipan (bank), kapan pun si penitip (nasabah) menghendaki. Mudharabah adalah perjanjian atas suatu jenis kerja sama usaha yang dalam hal ini pihak pertama menyediakan dana dan pihak kedua bertanggung jawab atas pengelolaan usaha. Pihak yang menyediakan dana biasa disebut dengan istilah shahibul maal, sedang pihak yang mengelola usaha biasa disebut dengan istilah mudharib. Keuntungan hasil usaha dibagikan sesuai dengan nisbah bagi hasil yang disepakati bersama sejak awal. Akan tetapi, jika terjadi kerugian, shahibul maal akan menanggung kerugian tersebut sedangkan mudharib tidak dengan dasar kerugian bukan terjadi karena kelalaian mudharib. Namun jika terjadi kerugian berdasarkan kelalaian mudharib maka kerugian ditanggung mudharib (Mulyo, 2012).

\subsection{Profit Distribution Management (PDM)}


PDM merupakan distribusi hasil usaha, distribusi pendapatan (Mawardi, 2005) dan distribusi bagi hasil (Antonio, 2001). Menurut Agustianto (2008) dalam (Mulyo, 2012), bagi hasil adalah keuntungan/hasil yang diperoleh dari pengelolaan dana baik investasi maupun transaksi jual beli yang diberikan kepada nasabah. Menurut Bank Indonesia, distribusi bagi hasil adalah pembagian keuntungan bank syariah kepada nasabah simpanan berdasarkan nisbah yang disepakati setiap bulannya. Jadi bisa disimpulkan secara singkat Profit Distribution Management merupakan aktivitas yang dilakukan manajer dalam mengelola pendistribusian laba untuk memenuhi kewajiban bagi hasil bank syariah kepada nasabahnya. Sundararajan (dalam Farook dkk., 2009) menemukan bahwa beberapa bank dalam sampel penelitiannya melakukan PDM yang mengacu pada suku bunga. Farook dkk. (2009), dalam sampel penelitiannya juga menemukan bahwa Indonesia cenderung melakukan PDM yang lebih tinggi dari beberapa bank lainnya. Untuk menghitung PDM yang mengacu pada suku bunga ini, dapat digunakan Asset Spread.

\subsection{Dana Pihak Ketiga (DPK)}

Menurut Farook (2012), Proporsi Dana Pihak Ketiga adalah proporsi atas dana yang diperoleh oleh bank yang dihimpun oleh bank syari'ah tersebut, dimana dana tersebut merupakan dana uang masuk ke bank syari'ah, yang berasal dari nasabah selain dana dari pemodal maupun peminjam. PDPK juga merupakan salah satu faktor yang memberikan informasi, dimana dapat menggambarkan seberapa besar bank syari'ah itu membutuhkan dana dari para nasabahnya. Jika dana tidak cukup, bank syari'ah tidak mampu melakukan kegiatan operasionalnya dengan maksimal atau bahkan menjadi tidak berfungsi sama sekali.

\subsection{Biaya Operasional terhadap Pendapatan Operasional (BOPO)}

Menurut Riyadi (2004), Biaya Operasional per Pendapatan Operasional adalah rasio yang digunakan untuk mengukur tingkat efisiensi dan kemampuan bank dalam melakukan kegiatan operasionalnya. Rasio BOPO merupakan rasio yang menunjukkan besaran perbandingan antara beban atau biaya operasional terhadap pendapatan operasional suatu perusahaan pada periode tertentu.

\subsection{Financing to Deposit Ratio (FDR)}

Financing to Deposit Ratio (FDR) adalah perbandingan antara pembiayaan yang diberikan oleh bank dengan dana pihak ketiga yang berhasil dikerahkan oleh bank (Muhammad, 2005). Rasio FDR yang analog dengan Loan to Deposit Ratio (LDR) pada bank konvensional adalah rasio yang digunakan untuk mengukur tingkat likuiditas bank yang menunjukkan kemampuan bank untuk memenuhi permintaan kredit dengan menggunakan total aset yang dimiliki bank. (Dendawijaya, 2003). Nilai FDR yang diperkenankan oleh Bank Indonesia adalah pada kisaran 78\% hingga 100\%.

\subsection{Ukuran Bank Syariah}

Ukuran bank adalah suatu skala yang dapat diklasifikasi besar kecil bank menurut berbagai cara, antara lain: total aktiva, log size, nilai pasar saham, dan lainlain. Ukuran bank merupakan salah satu penentu internal karena ekspansi perusahaan adalah tanggung jawab manajemen bank. Ukuran bank menurut Boyd dan Runkle 
(1993) adalah ukuran bank sering dikaitkan dengan konsep Economic of Scale. Teori ekonomi menjelaskan bahwa jika suatu industri yang mengalami Economic of Scale, institusi bisa lebih efisien untuk menghasilkan biaya yang lebih rendah. Diharapkan bahwa ekonomi skala atau ukuran bank yang positif berkaitan dengan profitabilitas bank.

\subsection{Kecukupan Modal (CAR)}

Kecukupan Modal menggambarkan kemampuan bank dalam mempertahankan modal yang mencukupi untuk menutup risiko kerugian yang mungkin timbul dari penanaman dana dalam aset produktif yang mengandung risiko, serta untuk pembiayaan dalam aset tetap dan investasi. CAR dapat digunakan untuk mengukur kecukupan modal pada bank syariah (Muhammad, 2009). Menurut Yuliani (2007), CAR juga biasa disebut dengan rasio kecukupan modal, yang berarti jumlah modal sendiri yang diperlukan untuk menutup risiko kerugian yang mungkin timbul dari penanaman aset yang mengandung risiko serta membiayai seluruh benda tetap dan inventaris bank.

\subsection{Populasi dan Sampel}

Populasi adalah keseluruhan subjek penelitian, populasi dalam penelitian ini adalah seluruh Bank Umum Syariah di Indonesia. Sampel adalah bagian atau wakil populasi yang akan diteliti (Arikunto, 2009:131). Teknik pengambilan sampel dalam penelitian ini menggunakan teknik Purpossive Sampling yaitu teknik pengambilan sample dengan mempertimbangkan kriteria-kriteria tertentu, yaitu perusahan yang memiliki data yang dibutuhkan dalam penelitian ini.

\subsection{Analisis dan Hasil Penelitian}

\section{1) Uji Asumsi Klasik}

Uji normalitas bertujuan untuk menguji apakah dalam model regresi, variabel terikat dan variabel bebas keduanya mempunyai distribusi normal ataukah tidak. Model regresi yang baik adalah memiliki distribusi data normal atau mendekati normal. Normalitas dapat dideteksi menggunakan uji statistik, yaitu KolmogorovSmirnov Test. Adapun hasil Pengujiannya tersaji dalam Tabel 1. Berdasarkan tabel 1 diketahui bahwa nilai signifikansi uji kolmogorov smirnov sebesar 0.991. karena nilai signifikasinya lebih dari 0.05 , maka disimpulkan bahwa data dalam penelitian ini berdistribusi normal.

Uji multikolinearitas dimaksudkan untuk menguji apakah model regresi ditemukan korelasi antara variabel bebas (independen). Apabila terjadi korelasi antara variabel bebas, maka terdapat problem multikolinearitas pada model regresi tersebut. Multikolinearitas dapat dilihat dari nilai tolerance dan Variance Inflation Factor (VIF). Jika VIF lebih dari 10 maka terjadi multikolinearitas. Hasil pengujian multikolinieritas selengkapnya dapat dilihat pada tabel Tabel 2. Berdasarkan tabel 2 diketahui bahwa nilai tolerance untuk semua variabel lebih dari 0.10 dan nilai VIF tidak lebih dari 10 sehingga dapat disimpulkan bahwa tidak terjadi multikolinieritas antar variabel bebas (independent) dalam penelitian ini. 
Uji autokorelasi bertujuan untuk menguji apakah dalam model terdapat adanya korelasi antara kesalahan pengganggu pada periode $t$ dengan kesalahan pengganggu pada periode t-1 (sebelumnya). Untuk menguji adanya autokorelasi dalam regresi linier berganda digunakan uji Durbin-Watson yang dapat dilihat pada tabel 3. Untuk mengetahui ada atau tidaknya auto korelasi baik positif maupun negatif digunakan rumus sebagai berikut :

\section{dU $<$ DW $<4-$ dU}

Berdasarkan tabel 3 diketahui bahwa nilai DW sebesar 1.874, sedangkan untuk mencari nilai dL dan dU dilihat dari tabel durbin Watson dengan $\mathrm{N} 32$ dan k sebesar 5 ( $\mathrm{k}=$ jumlah variabel bebas). Dengan N 32 dan k 5, maka diperoleh nilai dL sebesar 1.1092 dan dU sebesar 1.8187. Dari data diatas diketahui bahwa nilai DW lebih besar dari dU $(1.817<1.1874)$, nilai DW kurang dari 4-dU $(1.874<2.126)$. Karena nilai du<DW dan DW $<4-$ du, maka disimpulkan bahwa tidak terjadi autokorelasi positif atau autokorelasi negatif dalam penelitian ini.

Model regresi selain harus berdistribusi normal dan tidak mengandung multikolinieritas juga harus memenuhi syarat tidak adanya heteroskedastisitas. Uji heteroskedastisitas bertujuan untuk menguji apakah dalam model regresi terjadi ketidak samaan variance dari residual suatu pengamatan ke pengamatan yang lain. Model regresi yang baik adalah yang homoskedastisitas atau tidak terjadi heteroskedastisitas (Ghozali, 2005:105). Pengujian heteroskedastisitas dapat dilihat pula dari uji Glejser untuk meregres nilai absolute residual terhadap variabel bebas. Sebagai pengertian dasar, residual adalah selisih antara nilai observasi dengan nilai prediksi dan absolut adalah nilai mutlaknya. Adanya heterokedastisitas berarti adanya variabel dalam model yang tidak sama (konstan). Maka, dengan asumsi:

a) Jika nilai signifikan $>0,05$ maka tidak mengalami gangguan heteroskedastisitas.

b) Sebaliknya, jika nilai signifikan $<0,05$ maka mengalami gangguan heteroskedastisitas.

Berdasarkan uji statistik menggunakan SPSS 17.0 didapatkan hasil pada Tabel 4. Dari tabel 4 diperoleh nilai signifikan untuk semua variabel bebas lebih dari 0.05 , sehingga dapat disimpulkan bahwa data dalam penelitian ini tidak mengalami gangguan heteroskedastisitas.

\section{2) Pengujian Hipotesis}

Pengujian hipotesis menggunakan regresi linear berganda digunakan untuk mengetahui pengaruh variabel X terhadap Y. Hasil pengujian dapat dilihat pada tabel 5.

\section{a) Pengaruh Dana Pihak Ketiga (DPK) terhadap Profit Distribution Management (PDM)}

Berdasarkan tabel 5 diketahui bahwa nilai t hitung untuk variabel Dana Pihak Ketiga (DPK) sebesar -1.134 dengan nilai signifikasi 0.267. Karena nilai signifikasinya lebih dari nilai $\alpha$ sebesar 0,05. Maka dapat disimpulkan bahwa ukuran Dana Pihak 
Ketiga tidak berpengaruh secara signifikan terhadap Profit Distribution Management (PDM). Hal ini berarti H1 ditolak.

\section{b) Pengaruh Biaya Operasional Pendapatan Operasional (BOPO) terhadap Profit Distribution Management (PDM)}

Hasil pengujian hipotesis pada tabel 5 menunjukkan bahwa nilai t hitung untuk variabel Biaya Operasional Pendapatan Operasional (BOPO) sebesar -9.486 dengan nilai signifikasi 0.000 . Karena nilai signifikasinya kurang dari nilai $\alpha$ sebesar 0,05 . Maka dapat disimpulkan bahwa Biaya Operasional Pendapatan Operasional (BOPO) berpengaruh secara signifikan terhadap Profit Distribution Management (PDM). Hal ini berarti $\mathrm{H} 2$ diterima.

\section{c) Pengaruh Finance to Deposit Ratio (FDR) terhadap Profit Distribution Management (PDM)}

Berdasarkan tabel 5 diketahui bahwa nilai t hitung untuk variabel Finance to Deposit Ratio (FDR) sebesar -0.273 dengan nilai signifikasi 0.787. Karena nilai signifikasinya lebih dari nilai $\alpha$ sebesar 0,05. Maka dapat disimpulkan bahwa Finance to Deposit Ratio (FDR) tidak berpengaruh secara signifikan terhadap Profit Distribution Management (PDM). Hal ini berarti H3 ditolak.

\section{d) Pengaruh Ukuran Perusahaan terhadap Profit Distribution Management (PDM)}

Hasil pengujian hipotesis pada tabel 5 diketahui bahwa nilai thitung untuk variabel Ukuran Perusahaan 0.902 dengan nilai signifikasi 0.376. Karena nilai signifikasinya lebih dari nilai $\alpha$ sebesar 0,05. Maka dapat disimpulkan bahwa Ukuran Perusahaan tidak berpengaruh secara signifikan terhadap Profit Distribution Management (PDM). Hal ini berarti H4 ditolak.

\section{e) Pengaruh Capital Adequacy Ratio (CAR) terhadap Profit Distribution Management (PDM)}

Berdasarkan tabel 5 diketahui bahwa nilai t hitung untuk variabel Capital Adequacy Ratio (CAR)-2.285 dengan nilai signifikasi 0.031. Karena nilai signifikasinya kurang dari nilai $\alpha$ sebesar 0,05. Maka dapat disimpulkan bahwa Capital Adequacy Ratio (CAR) berpengaruh secara signifikan terhadap Profit Distribution Management (PDM). Hal ini berarti H5 diterima.

\section{PEMBAHASAN}

\section{a. Pengaruh Dana Pihak Ketiga (DPK) terhadap Profit Distribution Management (PDM)}

Dana Pihak Ketiga adalah proporsi atas dana yang diperoleh oleh bank yang dihimpun oleh bank syari'ah tersebut, dimana dana tersebut merupakan dana uang masuk ke bank syari'ah, yang berasal dari nasabah selain dana dari pemodal maupun peminjam. 
Dana Pihak Ketiga (DPK) menunjukkan seberapa jauh kemampuan bank dalam mengelola pembiayaan yang bersumber dari dana deposan. DPK dapat diukur dengan rasio FDR (Financing to Deposit Ratio). Tingkat bagi hasil (profit distribution) yang akan diterima deposan akan sangat bergantung pada jumlah dana yang disalurkan (tercermin dalam FDR), karena makin produktif dana yang dititipkan disalurkan dalam pembiayaan maka ada emungkinan bagi hasil yang diterima lebih besar.

Perusahan perlu mempertahankan likuiditas yang tinggi akan memperlancar customer relationship tetapi tingkat bagi hasil akan menurun karena banyaknya dana yang menganggur. Dilain pihak likuiditas yang rendah menggambarkan kurang baiknya posisi likuiditas suatu bank. Karena itu apabila DPK maka bagi hasil akan semakin tinggi juga. Hal tersebut bila dikaitkan dengan teori stakeholder, maka bank syariah akan mengurangi tingkat PDM yang mengacu pada suku bunga. Berkurangnya tingkat PDM dikarenakan bank telah mampu memanage deposannya dengan tingkat PDM yang sudah tinggi.

Dari hasil pengujian hipotesis diketahui bahwa Dana Pihak Ketiga tidak berpengaruh secara signifikan terhadap Profit Distribution Management (PDM). Hal ini dikarenakan proporsi dana pihak ketiga dalam penelitian ini sangat fluktuatif dan tidak merata. Hal ini dapat dilihat dari tingginya nilai standar deviasi pada variabel dana pihak ketiga (DPK) yang nilainya sebesar 15.99038, sehingga dalam menentukan Profit Distribution Management (PDM) perusahaan perbankan tidak mengacu pada dana pihak ketiga (DPK). Menurut Farook et al. (2009), salah satu penyebab bank syariah tidak menggunakan dana pihak ketiga (DPK) sebagai acuan dalam mengelola PDM yang mengacu pada suku bunga dikarenakan proporsi dana pihak ketiga yang lebih kecil daripada dana pemegang saham, Bank syariah tersebut kemungkinan lebih menyediakan PDM yang bersifat konsisten sesuai dengan asset returns yang diperoleh. Dengan demikian Proporsi Dana Pihak Ketiga (PDPK) tidak berpengaruh signifikan terhadap Profit Distribution Management (PDM). Artinya, besar kecilnya DPK yang menggambarkan seberapa besar ketergantungan bank terhadap dana deposan tidak menjadi ketentuan pihak bank dalam aktivitas Profit Distribution Management (PDM).

Hasil penelitian ini sejalan dengan penelitian yang dilakukan oleh Rizaludin dan Siswantoro (2013) dan Maulina (2013) yang menyimpulkan bahwa Dana Pihak Ketiga (DPK) tidak berpengaruh terhadap Profit Distribution Management (PDM).

\section{b. Pengaruh Biaya Operasional Pendapatan Operasional (BOPO) terhadap Profit Distribution Management (PDM)}

BOPO merupakan rasio antara biaya operasional terhadap pendapatan operasional. Biaya operasional merupakan biaya yang dikeluarkan oleh bank dalam rangka menjalankan aktivitas usaha utamanya seperti biaya bunga, biaya pemasaran, biaya tenaga kerja, dan biaya operasional lainnya. Semakin tinggi rasio ini akan semakin buruk kinerja bank, karena biaya yang dikeluarkan oleh bank lebih besar dibandingkan dengan pendapatan yang dihasilkannya. Dari pemaparan diatas dapat disimpulkan bahwa semakin besar BOPO maka akan menyebabkan profit distribution 
semakin kecil, hal ini disebabkan manajemen tidak efektif dalam mengelola perusahaan.

Dari hasil pengujian hipotesis diketahui bahwa variabel Biaya Operasional Pendapatan Operasional (BOPO) berpengaruh secara signifikan terhadap Profit Distribution Management (PDM). Nilai koefisien regresi BOPO bernilai negatif, hal ini berarti semakin tinggi rasio BOPO, maka profit distribution management (PDM) akan turun. Hal ini dikarenakan BOPO merupakan salah satu rasio untuk mengukur tingkat efisiensi bank, semakin tinggi rasio BOPO maka dapat dikatakan bahwa bank tidak efisien dalam menjalankan kegiatan usahanya, hal ini dikarenakan pendapatan yang dihasilkan hanya mampu digunakan untuk menjalankan kegiatan operasionalnya. Apabila sebuah bank syariah memiliki rasio BOPO yang tinggi, maka tingkat profit distribution management (PDM) semakin turun dan mendekati suku bunga bank konvensional, hal ini terjadi karena keuntungan yang dihasilkan hanya mampu menutupi kegiatan operasional perusahaan.

Hasil penelitian ini sejalan dengan penelitian yang dilakukan oleh Rizaludin dan Siswantoro (2013), dan Maulina (2013) yang menyimpulkan bahwa BOPO berpengaruh terhadap Profit Distribution Management (PDM).

\section{c. Pengaruh Finance to Deposit Ratio (FDR) terhadap Profit Distribution Management (PDM)}

Financing to Deposit Ratio (FDR) adalah Rasio pembiayaan terhadap dana pihak ketiga yang diterima oleh bank. FDR digunakan untuk bank syariah, sedangkan LDR untuk bank umum. Menurut Suryani (dalam Rizaludin dan Siswantoro, 2013) bahwa "Financing to Deposit Ratio (FDR) merupakan rasio yang digunakan untuk mengukur likuiditas suatu bank dalam membayar kembali penarikan dana yang dilakukan deposan dengan mengandalkan pembiayaan yang diberikan sebagai sumber likuiditasnya, yaitu dengan cara membagi jumlah pembiayaan yang diberikan oleh bank terhadap Dana Pihak Ketiga (DPK)". Kemudian likuiditas yang rendah menggambarkan kurang baiknya posisi likuiditas suatu bank. Sehingga bisa dikatakan financing to deposit ratio bisa berpengaruh negatif terhadap Profit Distribution Management.

Berdasarkan hasil pengujian hipotesis diketahui bahwa variabel Finance to Deposit Ratio (FDR) tidak berpengaruh secara signifikan terhadap Profit Distribution Management (PDM). Hal ini disebabkan perusahaan tidak efektif dalam mengelola dana nasabah dimana rata-rata FDR dalam penelitian ini sebesar 92.3397 yang artinya penyaluran pembiayaan belum maksimal. Disamping itu, pemanfaatan dana untuk kegiatan operasional lainnya (non kredit, investasi perbankan) juga belum optimal. Padahal pendapatan diperoleh tidak semata-mata dari penyaluran kredit, sehingga FDR tidak signifikan terhadap Profit Distribution Management. Apabila Efektivitas Dana Pihak Ketiga yang diukur dengan rasio Financing to Deposit Ratio (FDR) semakin tinggi, maka bagi hasil akan semakin tinggi juga. Hal tersebut bila dikaitkan dengan teori stakeholder, maka Bank Umum Syari'ah akan mengurangi tingkat PDM yang 
mengacu pada suku bunga. Berkurangnya tingkat PDM, dikarenakan bank telah mampu memanage deposannya dengan Profit Distribution yang sudah tinggi.

Hasil penelitian ini sejalan dengan penelitian yang dilakukan oleh Maulina (2013) dan Rizaludin dan Siswantoro (2013) yang menyimpulkan bahwa FDR tidak berpengaruh terhadap Profit Distribution Management (PDM)

\section{d. Pengaruh Ukuran Perusahaan terhadap Profit Distribution Management (PDM)}

Ukuran perusahaan adalah suatu skala yang dapat diklasifikasi besar kecil perusahaan dengant berbagai cara, antara lain: total aktiva, log size, nilai pasar saham, dan lain-lain. Ukuran bank merupakan salah satu penentu internal karena ekspansi perusahaan adalah tanggung jawab manajemen bank. Ukuran bank sebagai salah satu variabel independen karena secara teoritis dalam mikroekonomi sebuah bank besar dapat menciptakan skala ekonomi yang menurunkan biaya rata-rata dan memiliki dampak positif pada keuntungan bank. Masyarakat akan cenderung menyimpan uangnya di bank dengan skala ekonomi yang besar karena masyarakat berpikir akan merasa aman menyimpan dananya di sana. Oleh karena itu ukuran bank-bank syariah mempunyai pengaruh searah dengan profitabilitas bank yang akan diperoleh dengan penekanan efektivitas pengalokasiannya. Sehingga ukuran bank syariah mempunyai hubungan dan pengaruh positif terhadap profit distribution management yang dikelola oleh bank syariah.

Berdasarkan hasil pengujian hipotesis diketahui bahwa Ukuran Perusahaan tidak berpengaruh secara signifikan terhadap Profit Distribution Management (PDM). Hal ini disebabkan semakin tinggi ukuran suatu bank tidak mampu menjadi tolak ukur adanya aktivitas peningkatan PDM oleh manajer bank yang bersangkutan. Aktivitas PDM lebih condong dilakukan sebagai hasil dari decision making yang dibuat manajer atas kondisi keuangan bank dan kondisi pasar.

Ukuran Bank Umum Syari'ah Memiliki kecenderungan yang kuat dalam menghasilkan profit yang tinggi. Arah hubungan yang timbul antara ukuran ukuran bank Syari'ah terhadap Profit Distribution Management adalah positif yang berarti semakin banyak atau tingginya aset suatu Bank Umum Syari'ah Maka deposan akan menyimpan dananya di Bank dan itu akan mempengaruhi Profit Distribution Management Bank.

Hasil penelitian ini sejalan dengan penelitian yang dilakukan oleh Syahputra (2016) yang menyimpulkan bahwa ukuran bank tidak berpengaruh terhadap profit distribution management.

\section{e. Pengaruh Capital Adequacy Ratio (CAR) terhadap Profit Distribution Management (PDM)}

Rasio kecukupan Modal menggambarkan kemampuan bank dalam mempertahankan modal yang mencukupi untuk menutupi risiko kerugian yang 
mungkin timbul dari penanaman dana dalam aset-aset produktif yang mengandung risiko, serta untuk pembiayaan dalam aset tetap dan investasi. Kecukupan modal diukur dengan rasio CAR (Capital Adequacy Ratio). Penetapan CAR pada tingkat tertentu dimaksudkan agar bank memiliki kemampuan modal yang cukup untuk meredam kemungkinan timbulnya risiko sebagai akibat berkembang atau meningkatnya ekspansi aset terutama aset yang dikategorikan dapat memberikan hasil dan sekaligus mengandung risiko. Tingginya rasio ini dapat melindungi nasabah dan dapat meningkatkan kepercayaan nasabah terhadap bank (Rahman, 2004).

CAR yang tinggi membuat bank mampu meredam risiko-risiko yang muncul. Sehingga manajer bank lebih berani melakukan Profit Distribution Management yang mengacu pada suku bunga dikarenakan bank sedang dalam kondisi yang aman.

Berdasarkan hasil pengujian hipotesis diketahui bahwa CAR berpengaruh secara signifikan terhadap Profit Distribution Management (PDM). Nilai koefisien regresi CAR bernilai negatif, ini berarti semakin tinggi CAR maka kana menyebabkan PDM turun, hal ini disebabkan adanya kebijakan perusahaan untuk membagikan profit lebih sedikit guna meningkatkan meningkatkan permodalan untuk menjamin adanya ruang pertumbuhan usaha dan jaringannya. Kebijakan bank umum syariah membagikan profit lebih sedikit dikarenakan adanya tren positif pertumbuhan perusahaan perbankan di Indonesia, selain itu dukungan terhadap perbankan syariahpun sangat besar, seperti adanya fatwa MUI yang menganjurkan untuk menggunakan produk jasa perbankan syariah,

Hasil penelitian ini sejalan dengan penelitian yang dilakukan oleh Maulina (2013) yang menyimpulkan bahwa CAR berpengaruh terhadap profit distribution management.

\section{KESIMPULAN}

a. Dana pihak ketiga (DPK) tidak berpengaruh signifikan terhadap profit distribution management (PDM).

b. BOPO berpengaruh signifikan terhadap profit distribution management (PDM).

c. Finance to deposit ratio (FDR) tidak berpengaruh signifikan terhadap profit distribution management (PDM).

d. Ukuran bank tidak berpengaruh signifikan terhadap profit distribution management (PDM).

e. Capital adequacy ratio (CAR) berpengaruh signifikan terhadap profit distribution management (PDM). 


\section{DAFTAR PUSTAKA}

Antonio, M. Syafi' i.2001. Bank Syariah : Dari Teori Ke Praktek. Jakarta : Gema Insani Press.

Arikunto, S., 2009. Prosedur Penelitian Suatu Pendekatan Praktik. Edisi Revisi 6. Jakarta : Rineka Cipta.

Bank Indonesia. 2004. Surat Edaran Bank Indonesia Nomor 6/23/DPNP Perihal Sistem Penilaian Tingkat Kesehatan Bank. www.bi.go.id.

Boyd, J.H., dan Runkle, D.E., (1993), Size and Performance of banking firms: Testing The Prediction of Theory. Jurnal of Monetary Economics 31, 47-67

Dendawijaya, Lukman. 2003. Manajemen Perbankan. Jakarta : Ghalia Indonesia.

Farook dkk., 2009. Profit Distirbution Management By Islamic Banks. An Empirical Investigation. The Quarterly Review of Economics and Fina e 52

Ghozali, Imam. 2007. Aplikasi Analisis Multivariate Dengan Program SPSS. Universitas Diponegoro. Semarang

Husnelly. 2003. Analisis Faktor-Faktor Yang Mempengaruhi Investasi Dana Masyarakat Pada Bank Syariah (Studi Kasus Pada BSM). Tesis PSKTTI

Ikatan Akuntansi Indonesia. 2009. Standar Akuntansi Keuangan. PSAK. No.105: Akuntansi Mudharabah. Jakarta Salemba Empat

Karim, Adiwarman dan Afif. 2005. Islamic Banking Behaviour in Indonesia: a Qualitative Approach. 6th Conference On Islamic Economics and Finance. Jakarta, Indonesia, p.52.

Khairunnisa, Delta. 2002. Preferensi Masyarakat Terhadap Bank Syariah (Studi Kasus Bank Muamalat Indonesia dan BNI Syariah). Simposium Nasional. Yogyakarta: Sistem Ekonomi Islam, P3EI-FEUII.

Maulina, 2013. "Faktor-Faktor Yang Mempengaruhi Profit Distribution Management Atas Simpanan Deposan Pada Bank Syariah Di Indonesia PERIODE 2008-2012". Proceeding The 2 Corporate Sustainability Conference

Majelis Ulama Indonesia, Fatwa DSN No. 15/DSNMUI/ IX/2000 Tentang prinsip hasil usaha dalam lembaga keuangan syariah pada ketentuan umum Prinsip Distribusi Hasil Usaha. mui.or.id

Mawardi, Nasrah. 2005. "Faktor-Faktor Yang Mempengaruhi Penetapan Return Bagi Hasil Deposito Mudharabah Muthlaqah". Tesis S2 UI

Muhamad. 2009. Modul Short Course Bank Syariah. Yogyakarta : STEI

Muhlis. 2011. Perilaku Menabung Di Perbankan Syariah Jawa Tengah. Disertasi diterbitkan.Yogyakarta : Program Studi Doktor Ilmu Ekonomi Universitas Diponegoro Semarang. 
Mulyo, Gagat Panggah. 2012. Faktor-faktor yang mempengaruhi Profit Distribution Management atas simpanan deposan pada bank syariah di Indonesia periode 2008-2011. Skripsi S1 Undip

Prasetya, Frendy. 2011. "Analisis Pengaruh Diferensiasi, Promosi dan Positioning Terhadap Keputusan Pembelian”. Skripsi S1 UNDIP,

Riyadi, Slamet. 2004. Banking Asset \& Liabillity Management. Lembaga Penerbit Fakultas Ekonomi, Universitas Indonesia. Edisi ke-2: Jakarta

Rizaludin, Muhammad dan Siswantoro, Dodik. 2013. Analisis Pengaruh VariabelVariabel Determinan Atas Profit Distribution Management Terhadap Para Nasabahnya Pada Bank Syariah di Indonesia. Skripsi Universitas Indonesia

Syahputra, Irhas. 2016. Faktor-Faktor Yang Mempengaruhi Profit Distribution Management Pada Bank Umum Syari'ah Di Indonesia Periode 2011-2014. Skripsi S1 USU

Sugiyono. 2001. Metode Penelitian Bisnis. Cetakan Kelima : Penerbit CV. Alfabeta: Bandung

Susilo, Y. Sri. 1999. Bank dan Lembaga Keuangan Lainnya. Jakarta: Fakultas Ekonomi Universitas Indonesia.

Yaya, Rizal dkk. 2009.. Akuntansi Perbankan Syariah (Teori dan Praktik Kontemporer). Jakarta: Salemba Empat.

Yuliani, 2007. “Hubungan Efisiensi Operasional dengan Kinerja Profitabilitas Pada Sektor Perbankan Yang Go Public Di Bursa Efek Jakarta", Jurnal Manajemen dan Bisnis Sriwijaya, Vol 5, No 10,

Undang-undang No. 21 Tahun 2008 Tentang Perbankan Syariah, 
Lampiran

Tabel 1

Uji Normalitias

One-Sample Kolmogorov-Smirnov Test

\begin{tabular}{|c|c|c|}
\hline & & Unstandardized Residual \\
\hline & $\mathrm{N}$ & 32 \\
\hline Normal Parameters ${ }^{\mathrm{a}, \mathrm{b}}$ & Mean & .0000000 \\
\hline & Std. Deviation & .36961482 \\
\hline Most Extreme Differences & Absolute & .056 \\
\hline & Positive & .052 \\
\hline & Negative & -.056 \\
\hline & Kolmogorov-Smirnov Z & .314 \\
\hline & Asymp. Sig. (2-tailed) & .991 \\
\hline
\end{tabular}

a. Test distribution is Normal.

b. Calculated from data.

Tabel 2

Uji Multikolinieritas

Coefficients $^{\mathrm{a}}$

\begin{tabular}{|c|c|c|c|}
\hline \multirow{2}{*}{\multicolumn{2}{|c|}{ Model }} & \multicolumn{2}{|c|}{ Collinearity Statistics } \\
\hline & & Tolerance & VIF \\
\hline \multirow[t]{5}{*}{1} & DPK & .415 & 2.410 \\
\hline & BOPO & .688 & 1.453 \\
\hline & FDR & .725 & 1.379 \\
\hline & Ln_Total Asset & .353 & 2.829 \\
\hline & CAR & .564 & 1.773 \\
\hline
\end{tabular}

a. Dependent Variable: PDM

MALIA, Vol. 2 No. 1 
Tabel 3

Uji Auto Korelasi Durbin Watson

Model Summary ${ }^{b}$

\begin{tabular}{|l|r|r|r|r|r|}
\hline Model & \multicolumn{1}{|c|}{$\mathrm{R}$} & \multicolumn{1}{|c|}{ R Square } & Adjusted R Square & $\begin{array}{c}\text { Std. Error of the } \\
\text { Estimate }\end{array}$ & Durbin-Watson \\
\hline 1 & $.898^{\mathrm{a}}$ & .806 & .769 & .40359 & 1.874 \\
\hline
\end{tabular}

a. Predictors: (Constant), CAR, FDR, DPK , BOPO, Ln_Total Asset

b. Dependent Variable: PDM

Tabel 4

Uji Heteroskedastisitas

Coefficients $^{a}$

\begin{tabular}{|c|c|c|c|c|c|c|}
\hline \multirow{2}{*}{\multicolumn{2}{|c|}{ Model }} & \multicolumn{2}{|c|}{ Unstandardized Coefficients } & \multirow{2}{*}{$\begin{array}{c}\text { Standardized Coefficients } \\
\text { Beta }\end{array}$} & \multirow[b]{2}{*}{$\mathrm{t}$} & \multirow[b]{2}{*}{ Sig. } \\
\hline & & B & Std. Error & & & \\
\hline 1 & (Constant) & -.221 & 1.279 & & -.173 & .864 \\
\hline & DPK & -.008 & .004 & -.572 & -2.027 & .053 \\
\hline & BOPO & -.001 & .005 & -.071 & -.324 & .748 \\
\hline & FDR & -.006 & .007 & -.176 & -.826 & .417 \\
\hline & Ln_Total Asset & .078 & .059 & .408 & 1.336 & .193 \\
\hline & CAR & .002 & .008 & .046 & .192 & .849 \\
\hline
\end{tabular}

a. Dependent Variable: Abs_res

Tabel 5

Uji Hipotesis (uji t)

Coefficients $^{\mathrm{a}}$

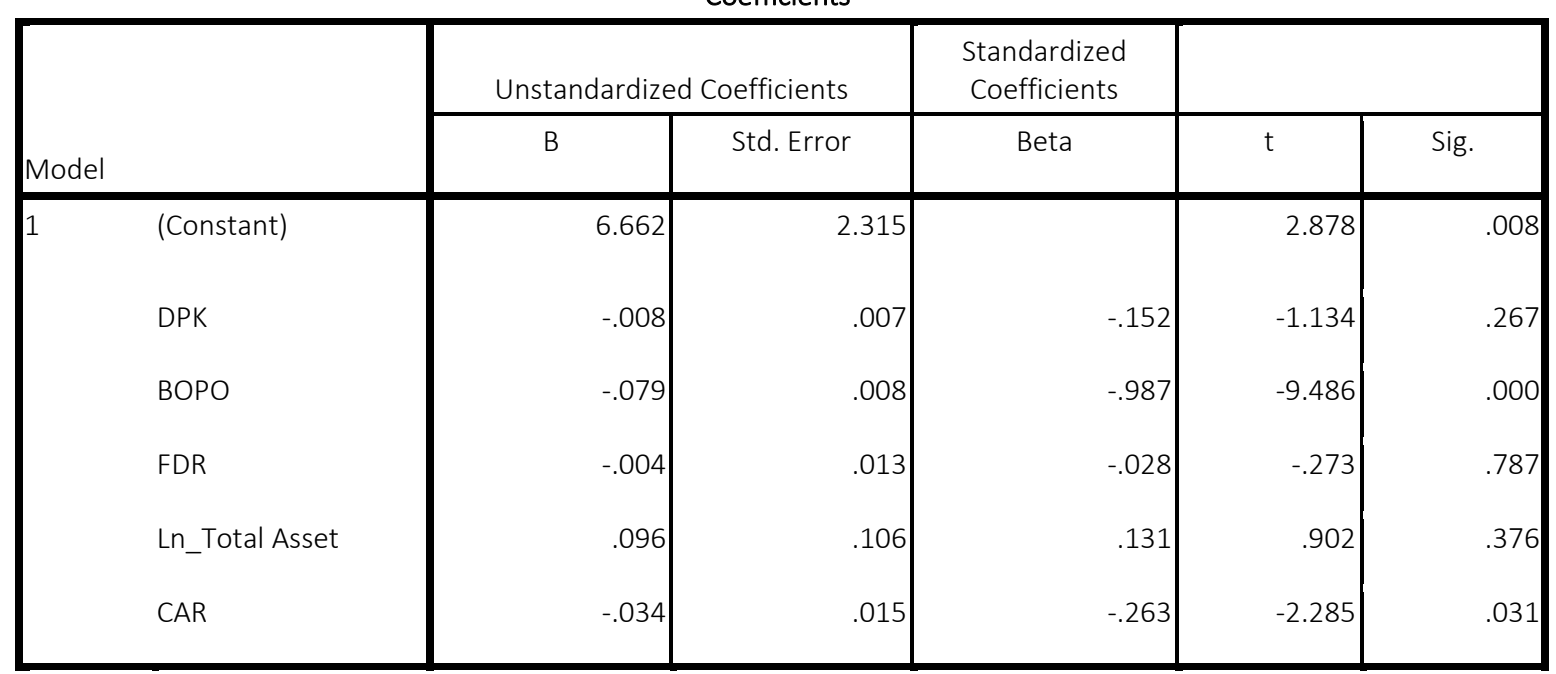

a. Dependent Variable: PDM 